Jakub Sosin

Informatyczne Centrum Edukacyjne

Myślenice

\title{
Rola programu PHARE w rozwoju przedsiębiorczości w Polsce w latach 1989-2004
}

Program PHARE powstał w 1989 r. jako pomoc Unii Europejskiej, początkowo tylko dla Polski i Węgier - państw kandydujących do Unii Europejskiej. Stąd nazwa złożona z pierwszych liter wyrazów tworzących pełny tytuł w języku angielskim: Poland-Hungary Assistance to Restructuring their Economies. Od 1990 r. jego działaniami zostały objęte także Bułgaria i Czechosłowacja, a następnie: Albania, Rumunia, Estonia, Litwa i Łotwa. Do 2000 r. korzystało z niego 17 państw Europy Środkowo-Wschodniej. Program został podzielony na kilka etapów:

- lata 1989-1991 - głównie pomoc doraźna,

- lata 1991-1994 - szkolenie i doradztwo,

- lata 1994-1997 - wspieranie inwestycji,

- od 1998 r. do czasu wstapienia do Unii Europejskiej - wspieranie procesu integracji.

Polska do tej pory otrzymała najwięcej środków w ramach tego programu. Do $2000 \mathrm{r}$. było to 21\% budżetu PHARE, czyli 2,5 mld euro. Z przewidzianego na lata 2000-2006 programu PHARE 2 korzysta dziesięć państw z Europy Środkowo-Wschodniej, w tym te, które kandydowały do Unii Europejskiej, a od 1 maja 2004 r. sąjej członkami, oraz niektóre kraje bałkańskie. Okres kontraktowania i realizacji programów zakończy się dopiero pod koniec 2006 r., a Polska, mimo że jest już członkiem UE, może z niego nadal korzystać (do wyczerpania środków), równocześnie korzystając z funduszy strukturalnych oraz Funduszu Spójności. Etap zamykania poszczególnych programów i rozliczenia końcowe potrwają do $2007 \mathrm{r}$. lub nawet do $2008 \mathrm{r}$. W ramach programu mogą być dofinansowane tylko projekty mieszczące się w zakresie wspólnych polityk UE.

Można wobec tego stwierdzić, że PHARE 2 jest swego rodzaju szkoła, wstępem do wykorzystywania funduszy strukturalnych i Funduszu Spójności. Łączy w sobie, w nieco uproszczonej i ograniczonej formie, możliwości tych funduszy.

Budżet PHARE 2 dla dziesięciu państw z Europy Środkowo-Wschodniej wynosi około 1,5 mld euro rocznie, a wszystkie realizowane w jego ramach projekty wymagają współfinansowania przez rząd, samorządy, organizacje pozarządowe lub firmy kraju otrzymującego pomoc. Wkład własny wynosi co najmniej 10\%, a najczęściej 20-40\%. Wyjątkiem są dotacje dla przedsiębiorstw; w ich wypadku wkład unijny nie jest wyższy niż 25\%. W systemie pomocy PHARE 2 wprowadzono podział finansów: $30 \%$ na wspieranie rozwoju instytucjonalnego i $70 \%$ na inwestycje.

Pieniądze na realizację projektów w ramach spójności społeczno-ekonomicznej, które mają służyć niwelowaniu różnic między regionami, są dostępne dopiero od 2000 r. Zasady wyboru inwestycji i sposobów ich realizacji są wzorowane na zasadach Europejskiego Funduszu Rozwoju Regionalnego (EFRR) i Europejskiego Funduszu Społecznego (EFS). Wykorzystują je 
przede wszystkim samorządy (ok. $100 \mathrm{mln}$ euro rocznie), głównie na projekty infrastrukturalne związane z transportem i ochroną środowiska. Część środków kieruje się na pomoc dla małych i średnich przedsiębiorstw, na doradztwo, szkolenia, finansowanie udziału w targach i inne działania wspierające rozwój (łącznie około $35 \mathrm{mln}$ euro rocznie, w tym około $20 \mathrm{mln}$ euro na dotacje do inwestycji).

Program PHARE 2 został podzielony na cztery edycje: PHARE 2000, PHARE 2001, PHARE 2002, PHARE 2003. W zależności od dziedziny wsparcia występował jako PHARE Spójność Społeczna i Gospodarcza - linia wspierająca działania analogiczne do Europejskiego Funduszu Rozwoju Regionalnego, oraz jako PHARE Rozwój Zasobów Ludzkich - linia wspierająca działania analogiczne do Europejskiego Funduszu Społecznego. W obu liniach programu znalazły się możliwości dofinansowania rozwoju, poprawy konkurencyjności, wzmocnienia funkcjonującej już działalności gospodarczej na poziomie małych i średnich przedsiębiorstw (MSP) oraz środki na wparcie powstających podmiotów gospodarczych. W początkowym okresie w ramach PHARE 2000 wyodrębniono Krajowy Program Rozwoju Małych i Średnich Przedsiębiorstw, którego środki były kierowane na wsparcie istniejącej działalności gospodarczej.

Do chwili obecnej ${ }^{1}$ zakończyły się i zostały rozliczone trzy linie programowe w ramach PHARE 2000 i 2001, przeznaczone wyłącznie na wspieranie działalności małych i średnich przedsiębiorstw (MSP), działające do maja 2004 r. Były to:

1. PL 0003.07 - PHARE 2000 - Krajowy Program Rozwoju Małych i Średnich Przedsiębiorstw

2. PL 0008 - PHARE 2000 - Spójność Społeczna i Gospodarcza

3. PL 0106.09 - PHARE 2001 - Spójność Społeczna i Gospodarcza

Alokację środków finansowych w poszczególnych województwach obrazują wykresy.

Ryc. 1. Wykorzystanie środków z programu PL 0003.07 - PHARE 2000 - Krajowy Program Rozwoju MSP w poszczególnych województwach

(tys. euro)

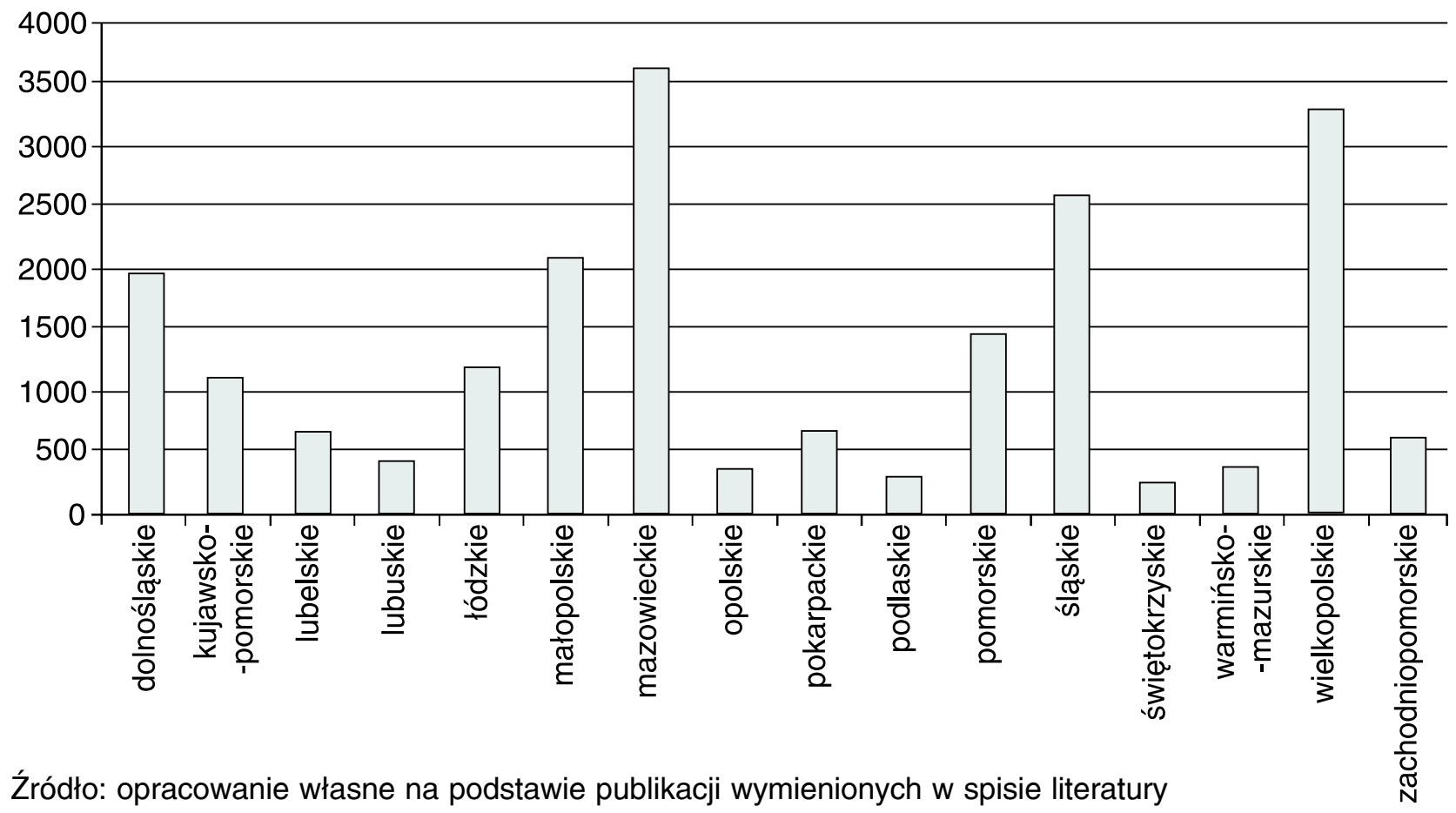

${ }^{1}$ I kw. 2006 r. [przyp. red.] 
Program PL 0003.07 - PHARE 2000 - Krajowy Program rozwoju Małych i Średnich Przedsiębiorstw był realizowany w całej Polsce. Jego łączny budżet to 21330000 euro, z czego 16000000 euro to środki UE, a 5330000 euro - środki budżetu państwa. Podzielony był na trzy linie, z których każda miała oddzielny budżet. Nie zostały określone żadne ograniczenia terytorialne, w związku z tym o środki z każdej linii mogły występować podmioty z całej Polski. Wyodrębniono następujące programy składowe:

1. „Wstęp do jakości” z budżetem 10670000 euro, z czego 8000000 euro to środki UE, a 2670000 euro - środki budżetu państwa,

2. „Innowacje i technologie” z budżetem 9330000 euro, z czego 7000000 euro to środki UE, a 2330000 euro - środki budżetu państwa,

3. „Przygotowanie do działań na rynku europejskim” z budżetem 1330000 euro, z czego

1000000 euro to środki UE, a 330000 euro to środki budżetu państwa.

Ze względu na brak ograniczeń terytorialnych nie można przedstawić przestrzennej alokacji środków. Brakuje również szczegółowych opracowań źródłowych, które umożliwiłyby szczegółową analizę alokacji środków na etapie ich wykorzystania. Najbardziej obszerne, choć niekompletne dane przedstawiaja podpisane umowy i procentowy rozkład liczby ostatecznych beneficjentów w poszczególnych województwach. Na tej podstawie przeprowadzono analizy, które - choć niewątpliwie obarczone błędem - pozwoliły na zobrazowanie przestrzennej alokacji środków zakontraktowanych w poszczególnych województwach. Wartości liczbowe przedstawia tab. 1.

Tab. 1. Podział zakontraktowanych środków w programie PL 0003.07 - PHARE 2000 - Krajowy Program Rozwoju Małych i Średnich Przedsiębiorstw według województw

\begin{tabular}{|l|c|l|c|}
\hline \multicolumn{1}{|c|}{ Województwo } & $\begin{array}{c}\text { Wartość umów } \\
\text { (w tys. euro) }\end{array}$ & \multicolumn{1}{|c|}{ Województwo } & \multicolumn{1}{c|}{$\begin{array}{c}\text { Wartość umów } \\
\text { (w tys. euro) }\end{array}$} \\
\hline dolnośląskie & 1967,7 & podkarpackie & 666,6 \\
\hline kujawsko-pomorskie & 1116,3 & podlaskie & 300,1 \\
\hline lubelskie & 662,5 & pomorskie & 1426,4 \\
\hline lubuskie & 382,6 & śląskie & 2569,5 \\
\hline łódzkie & 1245,0 & świętokrzyskie & 268,6 \\
\hline małopolskie & 2073,4 & warmińsko-mazurskie & 350,9 \\
\hline mazowieckie & 3637,4 & wielkopolskie & 3240,0 \\
\hline \multirow{2}{*}{ opolskie } & 334,9 & zachodniopomorskie & 616,9 \\
\cline { 3 - 4 } & & Polska ogółem & 20858,8 \\
\cline { 2 - 4 } & & &
\end{tabular}

Źródło: opracowanie własne na podstawie publikacji wymienionych w spisie literatury

Program PL 0008 - PHARE 2000 - Spójność Społeczna i Gospodarcza był realizowany w pięciu województwach: lubelskim, podkarpackim, podlaskim, śląskim i warmińsko-mazurskim. W jego skład wchodziły cztery programy:

1. Program Rozwoju Przedsiębiorstw,

2. Fundusz Dotacji Inwestycyjnych,

3. Program Rozwoju Przedsiębiorstw Eksportowych,

4. Tworzenie Środowiska Wspierającego Rozwój Regionalnej Przedsiębiorczości.

Programem objęto łącznie 2719 beneficjentów, a zrealizowane wsparcie wyniosło 34639 457,93 euro. Alokację przestrzenną środków przedstawia ryc. 2, a szczegółowy podział środków według poszczególnych województw i źródeł finansowania - tab. 2. 
Ryc. 2. Wykorzystanie środków z programu PL 0008 - PHARE 2000 - Spójność Społeczna i Gospodarcza w poszczególnych województwach

(tys. euro)

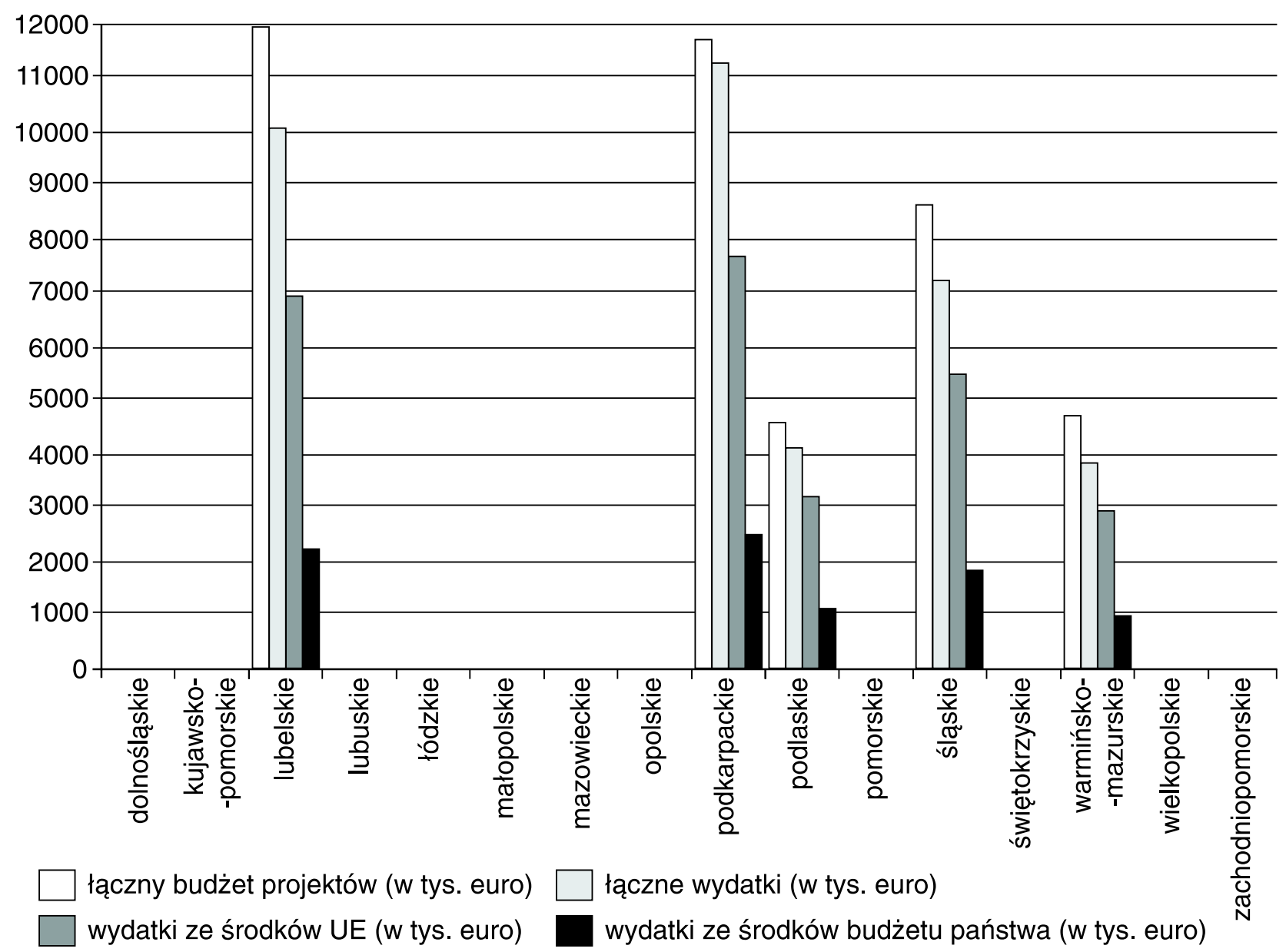

Źródło: opracowanie własne na podstawie publikacji wymienionych w spisie literatury

Tab. 2. Podział środków w programie PL 0008 - PHARE 2000 - Spójność Społeczna i Gospodarcza według województw i źródeł finansowania

\begin{tabular}{|l|c|c|c|c|}
\hline \multicolumn{1}{|c|}{ Województwo } & $\begin{array}{c}\text { Budżet } \\
\text { (w euro) }\end{array}$ & $\begin{array}{c}\text { Wydatki ze } \\
\text { środków UE } \\
\text { (w euro) }\end{array}$ & $\begin{array}{c}\text { Wydatki ze } \\
\text { środków budżetu } \\
\text { państwa (w euro) }\end{array}$ & $\begin{array}{c}\text { Wydatki lączne } \\
\text { (w euro) }\end{array}$ \\
\hline podlaskie & 4688543,00 & 3212380,59 & 1070793,54 & 4283174,13 \\
\hline lubelskie & 11008909,00 & 6885384,95 & 2295130,54 & 9180515,49 \\
\hline podkarpackie & 10791562,00 & 7647407,08 & 2548647,35 & 10196054,43 \\
\hline warmińsko-mazurskie & 4526012,00 & 2782258,47 & 927419,51 & 3709677,98 \\
\hline śląskie & 8630541,00 & 5454821,71 & 1815214,19 & 7270035,90 \\
\hline Razem & 39645567,00 & 25982252,80 & 8657205,13 & 34639457,93 \\
\hline
\end{tabular}

Źródło: opracowanie własne na podstawie publikacji wymienionych w spisie literatury

Program PL 0106.09 - PHARE 2001 - Spójność Społeczna i Gospodarcza był realizowany we wszystkich 16 województwach. W jego skład wchodziły cztery programy:

1. Fundusz Dotacji Inwestycyjnych, 3. Program Rozwoju Przedsiębiorstw Eksportowych, 2. Program Rozwoju Przedsiębiorstw, 4. Program Rozwoju Przedsiębiorstw Internetowych. 
Programem objęto łącznie 4576 beneficjentów, a zrealizowane wsparcie wyniosło 59153 560,40 euro. Alokację przestrzenną środków przedstawia ryc. 3.

Ryc. 3. Wykorzystanie środków z programu PL 0106.09 - PHARE 2000 - Spójność Społeczna i Gospodarcza w poszczególnych województwach

(tys. euro)

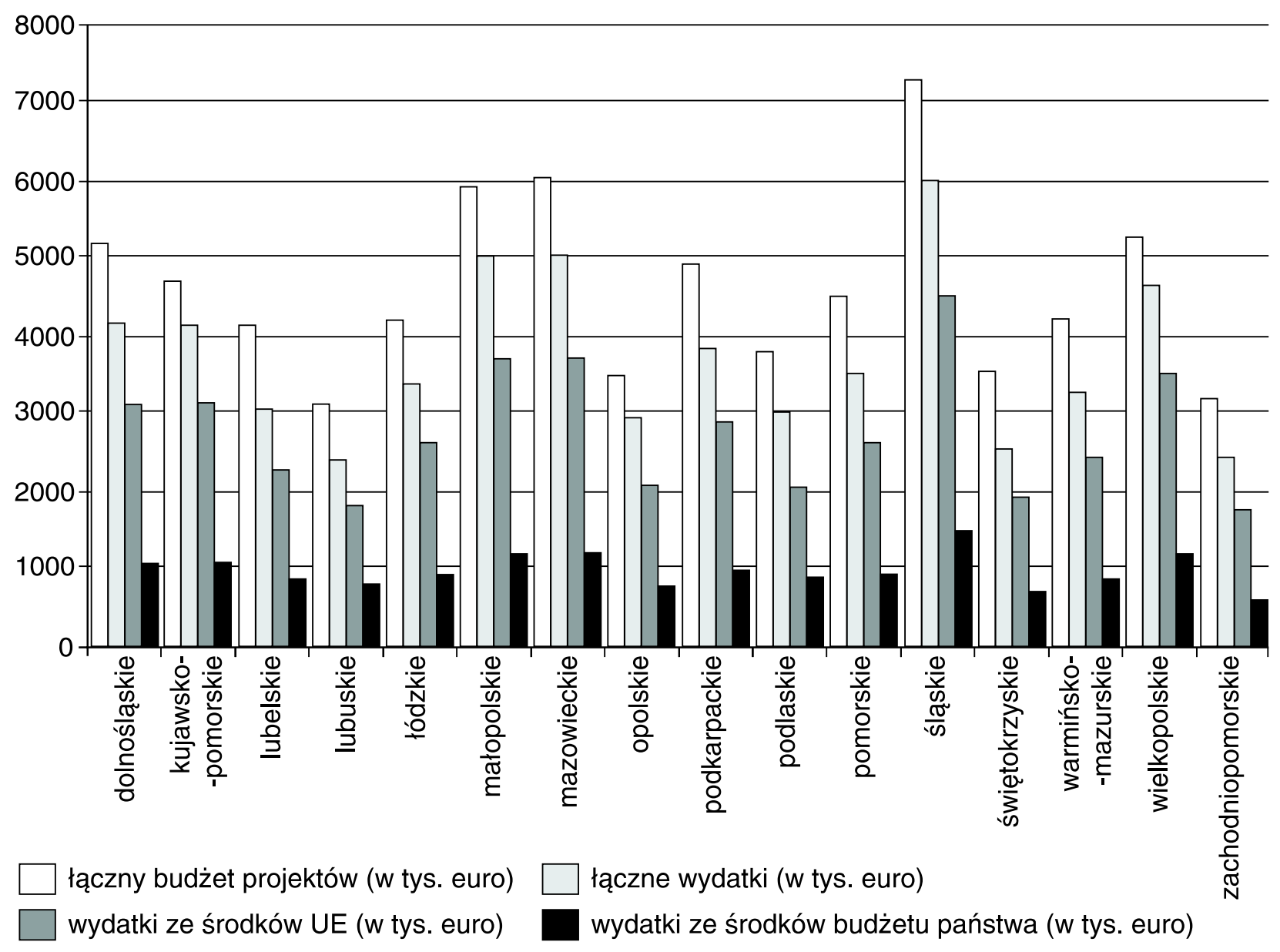

Źródło: opracowanie własne na podstawie publikacji wymienionych w spisie literatury

Szczegółowy podział środków według województw i źródeł finansowania przedstawia tab. 3.

Tab. 3. Podział środków w programie PL 0106.09 - PHARE 2001 - Spójność Społeczna i Gospodarcza według województw i źródeł finansowania

\begin{tabular}{|l|c|c|c|c|}
\hline \multicolumn{1}{|c|}{ Województwo } & Budżet (w euro) & $\begin{array}{c}\text { Wydatki ze } \\
\text { środków UE } \\
\text { (w euro) }\end{array}$ & $\begin{array}{c}\text { Wydatki ze } \\
\text { środków budżetu } \\
\text { państwa (w euro) }\end{array}$ & $\begin{array}{c}\text { Wydatki lączne } \\
\text { (w euro) }\end{array}$ \\
\hline \multicolumn{1}{|c|}{ (w } & 2 & 3 & 4 & 5 \\
\hline dolnośląskie & 5149600,00 & 3104544,48 & 1034847,55 & 4139329,03 \\
\hline kujawsko-pomorskie & 4616400,00 & 3095773,29 & 1031729,59 & 4127502,88 \\
\hline lubelskie & 4138666,67 & 2367946,07 & 789315,46 & 3157261,53 \\
\hline lubuskie & 3116000,00 & 1757662,79 & 585887,32 & 2343550,11 \\
\hline tódzkie & 4212400,00 & 2536163,94 & 839358,64 & 3375522,58 \\
\hline małopolskie & 5883800,00 & 3739151,53 & 1246383,31 & 4985534,84 \\
\hline mazowieckie & 6051000,00 & 3720777,21 & 1246958,86 & 4967736,07 \\
\hline
\end{tabular}


Tab. 3. Podział środków w programie PL 0106.09 - PHARE 2001 - Spójność Społeczna i Gospodarcza według województw i źródeł finansowania (cd.)

\begin{tabular}{|c|c|c|c|c|}
\hline 1 & 2 & 3 & 4 & 5 \\
\hline opolskie & 3413600,00 & 2163903,45 & 736290,88 & 2900194,33 \\
\hline podkarpackie & 4857333,33 & 2810235,69 & 934477,21 & 3744712,90 \\
\hline podlaskie & 3729333,33 & 2188035,58 & 814332,86 & 3002368,44 \\
\hline pomorskie & 4500800,00 & 2625260,03 & 878526,23 & 3503786,26 \\
\hline śląskie & 7329475,96 & 4504850,79 & 1501616,44 & 6006467,23 \\
\hline świętokrzyskie & 3373333,33 & 1954426,27 & 651475,31 & 2605901,58 \\
\hline warmińsko-mazurskie & 4234666,67 & 2472949,19 & 824316,45 & 3297265,64 \\
\hline wielkopolskie & 5260000,00 & 3443073,07 & 1147690,71 & 4590763,78 \\
\hline zachodniopomorskie & 3153466,67 & 1804200,44 & 601399,76 & 2405600,20 \\
\hline Razem & 73019875,96 & 44288953,82 & 14864606,58 & 59153560,40 \\
\hline
\end{tabular}

Źródło: opracowanie własne na podstawie publikacji wymienionych w spisie literatury

\section{Podsumowanie}

Program PHARE jest, a właściwie był, bardzo obszerny. Zmieniał się w trakcie realizacji. W bardzo wielu jego komponentach znajdowały się środki, które służyły pośrednio lub bezpośrednio rozwojowi przedsiębiorczości w Polsce. Opracowania na temat realizowanych działań to raporty ewaluacyjne i raporty z audytów. Wykonywane przez różne instytucje, prezentują różny stopień szczegółowości i różne podejście merytoryczne. Generalnie można zauważyć raczej podejście z punktu widzenia beneficjentów i beneficjentów ostatecznych niż alokacji przestrzennej środków. Inaczej mówiąc, zawierają one więcej informacji o tym, jak środki są wykorzystywane, niż gdzie są wykorzystywane. Wydają się zasadne dalsze prace nad całościowym obrazem wykorzystania środków PHARE na rozwój przedsiębiorczości w Polsce. Konieczne jest zatem zakończenie działań i rozliczenie wszystkich środków (nie wyklucza to jednak powstawania już obecnie opracowań dotyczących pierwszych okresów funkcjonowania programu).

Można również zauważyć, że w miarę upływu czasu raporty ewaluacyjne są coraz bardziej szczegółowe. Pozwoli to niewątpliwie w przyszłości na wykonywanie na ich podstawie różnorodnych i precyzyjnych opracowań.

\section{Literatura}

1. Raport końcowy z audytu programu PL 0003.07 - Phare 2000 - Krajowy Program Rozwoju MSP, DORADCA Auditors Sp. z o.o., Gdańsk/Warszawa, maj 2005 r.

2. Raport końcowy z audytu programu PL 0008 - Phare 2000 - Spójność Społeczna i Gospodarcza, DORADCA Auditors Sp. z o.o., Gdańsk/Warszawa, maj 2005 r.

3. Raport końcowy z audytu programu PL 0106.09 - Phare 2001 - Spójność Spoleczna i Gospodarcza, DORADCA Auditors Sp. z o.o., Gdańsk/Warszawa, maj 2005 r.

4. Raport końcowy Ewaluacja ex-post programu Wstęp do jakości (WdJ) w ramach Phare 2000 Krajowy Program Rozwoju MSP, Polska Agencja Rozwoju Przedsiębiorczości, Warszawa, lipiec 2005 r.

5. Raport końcowy Ewaluacja programu PHARE 2000 PL0003.07 Innowacje i technologie dla rozwoju przedsiębiorstw, Polska Agencja Rozwoju Przedsiębiorczości, Warszawa, grudzień 2005 r.

6. Lista dotacji przyznanych $\mathrm{w}$ ramach zaproszenia do składania wniosków o dotację Phare PL 0003.07.05.03 opublikowanego 21.05.2002 r. Zatwierdzone umowy dotacji termin październik 2002 r., http://www.parp.gov.pl/archiwum/dotacjephare 
7. Lista dotacji przyznanych w ramach zaproszenia do składania wniosków o dotację Phare PL 0003.07.05.03 opublikowanego 21.05.2002 r. Zatwierdzone umowy dotacji termin listopad 2002 r., http://www.parp.gov.pl/archiwum/dotacjephare

8. Lista dotacji przyznanych $\mathrm{w}$ ramach zaproszenia do składania wniosków o dotację Phare PL 0003.07.05.03 opublikowanego 21.05.2002 r. Zatwierdzone umowy dotacji termin grudzień 2002 r., http://www.parp.gov.pl/archiwum/dotacjephare

9. Lista dotacji przyznanych $\mathrm{w}$ ramach zaproszenia do składania wniosków o dotację Phare PL 0003.07.05.03 opublikowanego 21.05.2002 r. Zatwierdzone umowy dotacji termin luty 2003 r., http://www.parp.gov.pl/archiwum/dotacjephare

10. Lista dotacji przyznanych $\mathrm{w}$ ramach zaproszenia do składania wniosków o dotację Phare PL 0003.07.05.03 opublikowanego 21.05.2002 r. Zatwierdzone umowy dotacji termin marzec 2003 r., http://www.parp.gov.pl/archiwum/dotacjephare

11. Lista dotacji przyznanych w ramach zaproszenia do składania wniosków o dotację Phare PL 0003.07.05.03 opublikowanego 21.05.2002 r. Zatwierdzone umowy dotacji termin październik 2003 r., http://www.parp.gov.pl/archiwum/dotacjephare

12. Lista dotacji przyznanych w ramach zaproszenia do składania wniosków o dotację Phare PL 0003.07.05.03 opublikowanego 21.05.2002 r. Zatwierdzone umowy dotacji termin listopad 2003 r., http://www.parp.gov.pl/archiwum/dotacjephare

13. Lista dotacji przyznanych $\mathrm{w}$ ramach zaproszenia do składania wniosków o dotację Phare PL 0003.07.05.03 opublikowanego 21.05.2002 r. Zatwierdzone umowy dotacji termin grudzień 2003 r., http://www.parp.gov.pl/archiwum/dotacjephare

\section{The Role of the PHARE Programme in the Development of Enterprise in Poland 1989-2004}

The article shows the role of the PHARE programme in the development of enterprise in Poland 1989-2004. The programme was introduced in 1989 as the EU help, first only for Poland and Hungary, hence the name built of the first letters of the full English name „PolandHungary Assistance to Restructuring their Economies”. In 1990 countries like Albania, Romania, Estonia, Lithuania and Latvia joined the programme. Till 2000 seventeen countries in our region benefited from the programme. The programme was divided into some stages:

1989-1991 short-term help,

1991-1994 training and consultancy,

1994-1997 investment support,

from 1998 till joining the EU integration process support. It is Poland that has got the most funds from the programme so far (21\% of the PHARE budget, till 2000).

For the years 2000-2006 a programme called PHARE 2 was created. Ten countries from the middle-eastern Europe benefit from the programme, also the countries that were candidates and from $1^{\text {st }}$ May, 2004 are members of the EU as well as some Balkan countries. This programme had four editions: PHARE 2000, PHARE 2001, PHARE 2002, PHARE 2003 and, depend on the subject of help, appeared under different names.

PHARE programme is very wide and diverse. It was evolving during its realization. Funds from many of its components helped to develop enterprise in Poland, directly and indirectly. 